\title{
EDITORIAL
}

\section{Max Coates}

This second edition, of the well-received, Buckingham Journal of Education, gathers a series of articles around the educational legacy of the Rt. Hon. Michael Gove MP. This eclectic range of articles seeks to explore some of the facets of his influence, intention and policy from the period of 2010 through to 2014 when he was the Secretary of State for Education in the Conservative / Liberal Coalition.

The political landscape in the UK is never homogenous. Within the UK parliamentary power is apportioned through majority representation. However, at the regional level the political shade could be synchronous or asynchronous with that of central government. The optimistic view is that this creates a tension of checks and balances. The more pessimistic viewpoint is that local government of a different hue from that of central government presents obstacles and hinderance their policies and their execution. At the time of writing this editorial, this has been graphically illustrated by the 'Mexican standoff' between the conservative Prime Minister, Boris Johnson and the labour Mayor of Greater Manchester, Andy Burnham. This was over financial provision for Manchester in the face of Tier 3 restrictions relating to COVID19 and the potential increase in poverty in the city.

The 'Great Education Debate' initiated by the Prime Minister James Callaghan in 1976 was predicated on a desire to increase the control of central government. This was to receive its major genesis with the 1988 Educational Reform Act. Many of the milestones of that legislation will be familiar; devolvement of finance to schools, centralised inspection and the National Curriculum. The implementation of the legislation defined education at the local level. The tension described above was largely suppressed, with limited opportunity for dialogue.

What is fascinating is that whatever political party subsequently held sway there was a war of attrition waged against local authorities. I was a secondary headteacher from 1990 through to 2001. In the early part of that period school leaders wrestled with the practicalities of dealing with devolved budgets. The monies came to the local authority and were then controlled at the school level minus a 'top slice' which they retained to run their services. There was through this period an on-going debate as to the size of this retained money. The situation became more complex when central government instituted competitive tendering for established, local authority provided, services to include other potential providers. This included; payroll, catering, HR, legal services and grounds maintenance. The local authorities even found themselves bidding to carry out Ofsted inspections in their 'own' schools. 
Of course, every time a contract moved outside of the provision made by the local authority staffing cuts followed. A tipping point was reached when many of their services could no longer be maintained at economic levels.

The 'golden ticket' for this process of centralising education control was the separation of schools from their local authority. This included directly funding schools, such as academies, and offering some illusions of freedom in relation to teachers' contracts and removing them from the requirements of the National Curriculum. Overall, control was maintained by the coercive regime of school inspection.

Aside from trying to resolve the central and localised government tensions, the process of making schools quasi autonomous had considerable appeal to Liberal Democrat, Labour and Conservative parties. All three had embraced some level of neo-liberalism. This political philosophy placed an emphasis on a reductionist state, allied to a belief that the 'market' could shape improvement. Ball and Bailey (2015:128), in an article exploring the developing educational policy under the Conservative-Liberal Democrat government (2010-2015) suggested;

The marketisation and privatisation of education was ratcheted up by the coalition with the further mobilisation of new actors and agencies in the policy process - begun by New Labour - and there was a continuing move to open up service delivery to new providers and to offer some schools greater freedom and autonomy in order that they may innovate, diversify and 'drive up standards', and offer greater choice to parents and students as consumers.

If we backtrack to the early attempts to create state funded schools which were detached from local authority control it becomes apparent that it had a somewhat erratic genesis. In 1986 Kenneth Baker, the then Secretary of State for Education, announced the development of City Technology Colleges (CTCs). The following year the CTC Trust was established with Cyril Taylor as the chair. The intention was to partner - fund, with industry some 200 of these schools. They were 'parachuted' into areas without reference to the numbers on roll in nearby schools. They also disapplied established national contracts relating to the working conditions of teachers which included; hours of employment and pay and conditions.

From 1994 to 2010 there was an evolution from these very specific CTCs to the options of other schools bidding for specialist status with a focus on subject areas such as science, computing and languages. In 2002 Charles Clarke succeeded Estelle Morris as the Secretary of State for Education and removed an existing financial cap to encourage more schools to assume this status. The CTC Trust changed its name to the Specialist Schools Trust (SST) in 2003 with 2500 schools affiliating by the following year, though the overwhelming majority of these 
schools remained within the local authority orbit. A further name change took place in 2005 to the Specialist Schools and Academies Trust (SSAT). They had a central role under the Labour government in developing the government's academies programme.

In 2010, after an indecisive election result, the Conservative - Liberal Democrat Coalition was formed. The differential funding of these specialist schools came to an end along with the designation of specialisms. In 2012 it was announced that the SSAT was going into administration. Following a management buyout, parts of the trust were bought and the SSAT (The Schools Network) still continues to operate as a company delivering education improvement services.

Despite all of these initiatives to promote academies or academy type schools, when the Coalition took office in 2010, together with Michael Gove as Secretary of State for Education, the number of academy schools stood at 203. In 2015 the year after Gove left that office the number had risen to 4,722 (DfE 2016). Additionally, by 2015 the numbers of community or organisationally sponsored open free schools had now risen to 252 (DfE 2016). This is an extremely rapid increase in numbers with some schools converting and others being forced into the fold. In 2015 the then Prime Minister, David Cameron confirmed the continuation of this policy direction;

Over 4,000 schools are already benefitting from academy status, giving them more power over discipline and budgets. And nearly 800 of the worstperforming primary schools have been taken over by experienced academy sponsors with a proven track record of success. This is improving education for our children. So, we will continue to expand academies, free schools, studio schools and University Technical Colleges. Over the next parliament, we will open at least 500 new free schools, resulting in 270,000 new school places. And we will introduce new powers to force coasting schools to accept new leadership. (Conservative Party, 2015)

The pace of academisation had accelerated and Gove was a significant driver of this change.

May I suggest that you try a simple experiment. Take a piece of paper and list ten past holders of the office of Secretary of State for Education. Then note down beside their name any key policy initiatives with which they were associated. I would suggest that it is unlikely that you would have any of the following; on your list; Justine Greening, Ruth Kelly, John Patten, Fred Mulley and Mark Carlisle. You may well have the following; Nicky Morgan, Alan Johnson, Damian Hinds and the current post holder Gavin Williamson but you are probably less certain about policy initiatives associated with them. 


\section{EDITORIAL}

Almost certainly, Michael Gove would be on be on most of these lists. Further, that you will remember many of the initiatives and events linked with him; allowing schools rated by Ofsted as Outstanding to become academies, initiating 'Free Schools', terminating the Building Schools for the Future started by the previous Labour administration, famously apologising for getting the list of affected schools incorrect, reorganising his department, reforming A-Level and GCSE qualifications, the EBacc, abolishing modular units and coursework in many subjects in favour of final examinations and handling the Birmingham based Trojan Horse Scandal. In 2013 The National Association of Headteachers, The Association of Teachers and Lecturers, the National Union of Teachers and the NASUWT all passed motions of no confidence in his policies.

One is left feeling that if any commercial organisation had sponsored his tenure in education it would have to have been Marmite. However, my view remains that Michael Gove is one of the most influential Secretaries of State for Education in the last fifty years. It perhaps fitting that the biography by Bennett (2019) was entitled Michael Gove, A Man in a Hurry. A fitting summary?

It is hoped that the articles that follow reveal the complexity of the man. His journey from working class roots to politician has garnered some almost contradictory influences en route. I would suggest the following, though the list is not exhaustive:

1. The advocate of neoliberalism. This is probably the least surprising of the tenets held by Gove. With its roots in the thinking of the German sociologist, Alexander Rustow, neoliberalism had free market trade as its hallmark. It is plays down the role of the state and places a high level of faith in 'the markets. The Conservative - Liberal Democrat Coalition was 'guided by a vision of the weak state. Thus, what is private is necessarily good and what is public is necessarily bad' (Apple, 2000, p 59). Neoliberalism was embedded through the UK political stick of rock from Thatcher through New Labour and on into the coalition. There is an inherent appeal to taking complex problems, like education and adopting an almost Darwinian 'survival of the fittest' approach. Schools are placed in the hands of private providers and the effective come to dominate and those providers found wanting become extinct. Neoliberalism is a self-evident springboard to academisation and the creation of free schools.

2. Gove has held an ambivalent attitude towards teachers. As he left The Robert Gordon School to go to Oxford, he was to write this in a poem published in the school magazine:

'Tis hard to say, if greater want of skill

Appear in learning or in teaching ill; 
It seems to be that the teacher's twin offence

To tire our patience and mislead our sense.

Some few teach well, but they err in this,

They censure wrong and are in wit amiss.

(in Bennett 2019:18)

Gove continued to lecture teachers, but the basis of his judgement seemed to reside with a personal archetype. This apparent disdain was ultimately to lead to the cascade of motions of no confidence passed by the teaching unions towards the tenure of his ministerial post.

3. The Romantic. Gove was an inveterate reader as a teenager and beyond. He certainly developed a passion for English writers such as; Austen, Waugh, Orwell, Eliot and Powell. His historical perspective was more down the 'Empire' end of the spectrum. His passion for literature and a particular perception created a scotoma with his predilections moving from personal advocacy to becoming educational core.

At the moment, access to the best that has been thought and said is restricted to a fortunate few. Because of the dumbing-down of both our exams and school curricula under Labour, children can go through school never having read a novel written before the 20th century, never having read or seen an entire Shakespeare play, never having learned a poem by heart, never having had the chance to appreciate, or play, classical music, never having the chance to learn about the achievements of the greatest scientists and engineers, never having had the chance to play in the competitive sports in which England has long excelled, never being encouraged to engage with anything which is not immediately "relevant" to their lives.

(Gove 2013:2)

Gove was to propose a content rich curriculum, his distinctive views being enhanced by the stance of Hirsch. In a response to The Sunday Times (2014), the chair of the National Association for the Teaching of English, Bethan Marshall, argued: 'It's a syllabus out of the 1940s and rumour has it, Michael Gove, who read literature, designed it himself. Schools will be incredibly depressed when they see it.' (2014). He failed to grasp that conviction will not necessarily secure compliance.

4. Revolutionary. Despite a brief brush with being a member of The Labour Party in his youth, Michael Gove remains a staunch conservative. However, that 
political epithet does not always sit comfortably as a mantle. There is always something of the maverick, the radical about him. He has repeatedly stood up for social underdog both in his role as the Secretary of State for Education and subsequently as the Secretary of State for Justice. At one stage, he opposed the expansion of grammar schools and also held the 11plus to be a retrograde step. Famously, he had a picture of Lenin in his office at the Department for Education. Some have even questioned his credentials as a conservative. Young writing in The Spector describing him as 'the best leader of the labour party that never had' (2013). At various stages he has been closely associated with Dominic Cummings. Bennett quotes a friend of Gove, unattributed, who concluded:

What they have in common is an almost Leninist belief - almost Trotskyite belief perhaps - that you have to permanently revolutionise. Institutions have this incredibly strong drag effect and unless you are zealously fighting to push through your reforms they will die.

Perhaps at the heart of Michael Gove's political style is a driven restlessness that is satiated by maintaining an agitated momentum.

I contacted the Rt. Hon. Michael Gove MP to ask him to contribute to the journal. Characteristically courteous, he declined but wished us well. I have copied his letter after this editorial. The journal would, of course, be willing to allow him the right of reply to anything that we have published.

This journal is very much an activity of collaboration. Many thanks to all those who have contributed articles that engage with topics as varied as policy to phonics. Our intention is to maintain an eclectic mix of articles which present a variety of viewpoints. However, the inclusion of an article in the journal should not be taken as reflecting either the views of the editorial team or the University of Buckingham.

Again, my thanks to our Dean of Education, Professor Barnaby Lenon CBE for his continuing support and encouragement, our review panel for their advice. On the publishing side, thanks are due to Jonathan Reuvid MA, Editor in Chief, University of Buckingham Press and at Legend Press; Christian Müller, and Tom Chalmers the publisher of UBP and managing director of the Legend Times Group. Finally, and by no mean least Mark Deacon, our assistant editor, for his advice and unflagging suggestions of potential contributors.

\section{REFERENCES}

Apple, M.W. (2000) 'Between neoliberalism neoconservatism in a global context', in N.C. Burbules and C.A. Torres (eds) Globalization and education: critical perspectives, Abingdon: Routledge, pp. 57-77. 
Bailey, P. L. J., \& Ball, S. (2015). The coalition government, the general election and the policy ratchet in education: A reflection on the 'ghosts' of policy past, present and yet to come. In H. Bochell \& M. Powell (Eds.), The coalition government and social policy: Restructuring the welfare state (pp. 127-152). Bristol: Policy Press.

Bennett, O. (2019) Michael Gove, A Man in a Hurry. London: Biteback Publishing Ltd.

Conservative Party (2015) Stronger leadership, a clear economic plan, a brighter, more secure future, London: Conservative Party.

Department for Education (2016) Academies Annual Report Academic year: 2014 to 2015. London: Crown http://www.gov.uk/government/publications (accessed $1^{\text {st }}$ November 2020)

The Education Reform Act (1988) United Kingdom. London, Crown (available at: http://www.legislation.gov./ukpga/19888/40/section/1) (accessed $14^{\text {th }}$ October 2020)

Gove, M. (2013) Please Sir, I Just Want to Learn More. London: Standpoint https:// standpointmag.co.uk/tag/educating-rita/ (accessed 12 ${ }^{\text {th }}$ November 2020)

The Sunday Times (25 ${ }^{\text {th }}$ May 2014) Teaching Group Slams English Syllabus 'Out of the 1940s'. London: The Sunday Times (accessed $12^{\text {th }}$ November 2020)

Young, T. (2013) Why Michael Gove is the best leader Labour never had. London: The Spectator https://www.spectator.co.uk/article/why-michael-gove-is-thebest-leader-labour-never-had (accessed $19^{\text {th }}$ November 2020) 


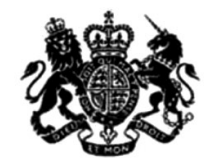

Rt Hon Michael Gove MP

Chancellor of the Duchy of Lancaster

Cabinet Office 70 Whitehall London SW1A 2AS

\section{Pos $\mathrm{An}_{\text {, }}$}

Thank you for your letter of 29 July thoughtfully inviting me to contribute to The Buckingham Journal of Education.

I cherish the time I spent as the Secretary of State for Education and am heartened that you would like to include my take on what was achieved at that time. As we make the most of the opportunities available at the end of the transition period and continue to restore our way of life after the pandemic, there are - as I am sure you can imagine - significant pressures on my diary. It is with regret, therefore, that I have to decline your offer at this time.

I wish you the best of luck with your ongoing research and look forward to reading your Journal when it is completed.

With every good wish,

lus.<smiles>C=CC=[14CH]</smiles><smiles>C1CCC1</smiles>

Rt Hon Michael Gove MP

Chancellor of the Duchy of Lancaster and Minister for the Cabinet Office 